\section{Economic Literature}

(Vol. XIII, August 2016)

(C) Department of Economics

Tribhuvan University

Prithvi Narayan Campus

Pokhara, Nepal

\section{Editorial Board}

Chief Editor

Mr. Deo Narayan Sutihar

Professor

Executive Editors

Dr. Lekha Nath Bhattarai

Professor

Assistant Editors

Mr. Dilli Ram Sharma

Mr. Ganesh Gautam

Mr. Kamal Dhakal

\section{Advisory Board}

Prof. Dr. Yadav Sharma Gaudel, Head, Dept. of Economics, PNC Prof. Dr. Bishwombhar Pyakurel, Ex-Head, Central Dept. of Economics, $T$
Prof Dr. Devi Prasad Bedari, School

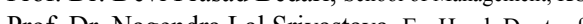

Prof. Dr. Om Prakash Sharma, Ex-Head, Dept. of Economics. PNC

Mr. Gorakh Raj Ojha, Ex-Head, Dept. of Economics, PNC

Mr. Prakash Man Gubhaju, Ex-Head, Dept. of Economics, PNC

Mr. Kunja Raj Thapa, Ex-Head, Dept. of Economics, PNC

Mr. Gehendreswor Koirala, Ex-Chief Editor, Economic Literature

Subscriptions

(Excluding mailing charge)

Nepal: Per Copy NRs. 200.00 (Individual) Per Copy NRs. 300.00 (Institution)

Abroad: Per Copy $\$ 40.00$

\section{Mailing Address}

Chief Editor

Economic Literature

Department of Economics

Prithvi Narayan Campus

Pokhara, Nepal

Email: lekhnath2020@gmail.com

\section{Editorial}

Editorial board has pleasure to release this issue of Economic Literature, an annual, peer reviewed Journal of Department of Economics, Prith Narayan Campus, Tribhuvan University, Polh (Volume XIII, August 2016). Th, Pokhar publication of this joust We have been publication of this journal. We have been making efforts to promote the general advancement of economic knowledge, information and techniques of analysis since 1981. Our aim is to continue this tradition by publishing highly academic and policy oriented research papers and to provide platforms for enthusiastic scholars who like to publish their scholarly and analytical paper based on fresh research on the issues of interest around the discipline of economics.

This issue incorporates analytical articles of contemporary issues of Nepalies economy including VAT, money supply, merger and acquisition of banks, effect of competition on financial stability, impact of remittance, customers' retension strategies of mobile survice provider and household economy of Chepang.

We strongly believe that University Departments should engage in research and disseminate the ideas and findings obtained through research to the scientific community for the enlightenment of knowledge, not just to deliver the existing knowledge in class rooms. We have firmly believed that it will not only enrich field of knowledge but also inspire the fresh gadd towards the culture of scientific research thought witings. If this publication corch and thoughtful writings. If this publication contributed something to strenghen the culture, we will feel great satisfaction. It is, however, up to the reader to evaluate our endeavour.

It was not possible to offer this volume to the esteemed readers without the contributions of the authors and reviewers of the articles included in this issue. We, therefore, reverentially acknowledge the authors and reviewers who have contributed to the journal. We would also like to thank to those who have assisted us by encouraging the course of this publication. Special thanks go to the campus administration for encouragement and support in various ways. The editorial board welcomes all the noble thoughts, constructive comments and suggestions.

\section{ECONOMIC LITERATURE}

Vol. XIII, August 2016

\section{Guidelines to Contributors}

- Research oriented and thought provoking articles, research papers and book reviews are welcome. The works submitted to the Journal must be in English and should not be submitted elsewhere for publication. The works in electronic form will be highly welcome along with a hard copy.

- The manuscript should be typed on one side of the paper in double space. The size must be limited in 5000 words.

- Every article should be accompanied by an abstract of about 150 words.

- Articles will be accepted on the condition that they are subject to editorial change and revision, if necessary.

- Mathematical formulas and symbols should be clearly typed/written. Diagrams, if any, should be clearly drawn.

- A complete list of references cited in the text should be provided and arranged alphabetically by author's' surname. The list should include the surname, name of author/s followed by publication year, the title of book, indication of edition if it is other than first, place of publication and the name of the publisher. If the reference is the article of the journal, title of the article be within inverted comma followed the name of Journal with volume and number should be given. Its all pages should be mentioned at the end. For web-based references, the website and the date of browsing should also be indicated along with other details. For example:

Amacher, G.S.; W.F. Hyde and K.R. Kanel (1999). Nepali feulwood production and consumption: regional and household distinction, substitution and successful intervention. The Journal of Development Studies, Vol.35 (4): 138-163.

Thapa, G.B. and K.E. Weber (1990). Managing Mountain Watershed: The Upper Pokhara Valley, Nepal. Bangkok: Asian Institute of Technology.

Sahoo, Sarbeswara (2010). 'Impact of global recession on the livelihood of diamond workers: a case study of Gujarat, India. http://www.global-labour-university.org [Accessed on 15 April 2010].

- The citation of reference at the running text will be followed as given in the current journal.

- The authors should provide their full address and designation.

- The articles are peer reviewed through annonimous reviewers. Authors are requested to revised their articles following to the comments given by reviewers.

- All communication should be addressed to: The Chief Editor, Economic Literature, Department of Economics, P.N. Campus, Pokhara, Nepal. The email address given in this Journal can be taken as the quickest means of communication. 